\title{
Investigation of Salt and precipitating agent effect on the specific surface area and compressive strength of alumina catalyst support
}

\author{
Mostafa Mahmoudian², Alireza Hemmati' ${ }^{1}$, Hasan Hashemabadi ${ }^{2}$, Ahad Ghaemi ${ }^{*}$, \\ Shahrokh Shahhosseini ${ }^{1}$ \\ ${ }^{1}$ Iran University of Science and Technology, Department of Chemical, Oil and Gas Engineering, P.O. Box: 16765-163, \\ Teheran, Iran \\ ${ }^{2}$ Deputy of Planning and Technology, Iran Alumina Complex, Jajarm, Iran \\ "Corresponding author: e-mail: aghaemi@iust.ac.ir
}

\begin{abstract}
Nowadays, catalyst supports are extensively used to decrease the costs and increase the contact surface area in chemical reactions. Specific surface area, compressive strength, pore volume and pore size are some of the most important characteristics of a catalyst support. In this work, Sol-gel and peptization methods were applied to produce alumina catalyst support. Also the roles of aluminum salts and precipitating agents on the specific surface area and compressive strength of alumina catalyst support were investigated. In addition, various additives and common methods in the increasing surface area, compressive strength and adjusting the porosity and pore size are used in this study. The results show that using caustic soda as precipitating agent and aluminum chloride salt yields catalyst supports with the best compressive strength. Also, using aluminum nitrate and ammonia as precipitating agent produced alumina catalyst support with the highest specific surface area.
\end{abstract}

Keywords: Alumina, Catalyst Support, Sol Gel, Specific Surface Area, Compressive Strength.

\section{INTRODUCTION}

Having a high available contact surface and economic advantages causes applying catalyst supports, to be enhanced in recent years. Alumina is among the catalyst support, which have been very frequently used in recent decades for many reactions, due to its extended range of specific surface area, compressive strength, pore volume and pore size, and its various phases ${ }^{1}$. Alumina catalyst support has many applications in the steam reforming ${ }^{2,3}$, desulfurization $^{4,5}$, oxidation of toluene ${ }^{6}$, methane and propane dehydration ${ }^{7,8}$, hydrogen production ${ }^{9,10}$, removal of the bacteria and odor gases ${ }^{11}$, hydrogenolysis of glyce$\mathrm{rol}^{12}$, and also in automobile exhaust catalytic converter and other petrochemical processes ${ }^{21,22}$. Extended applications of alumina as a catalyst or a catalyst support cause many scientists to do a lot of researches on producing and developing them. Many studies in these fields have also been done by using peptization ${ }^{12,13}$ and Sol-gel methods ${ }^{14-18}$. In addition, many researches have been conducted to investigate the effect of the considerable factors in the process, indicating time, temperature and $\mathrm{pH}$ of the reaction have significant influence on properties of catalyst supports produced by Sol-gel method ${ }^{19}$. Some studies show that calcination conditions have important effects on the characteristics of the alumina catalyst support ${ }^{20}$. Recent studies also revealed that the initial concentration of aluminum has a major impact on specific surface area, pore volume and pore size of the alumina catalyst support ${ }^{23-26}$. The $\mathrm{pH}$ of the solution is the another important parameter in producing alumina catalyst support ${ }^{27}$. The results show an increase in $\mathrm{pH}$ from 5 to 7, decreases the specific surface area and pore volume. It also increases the pore size of the catalyst support ${ }^{27}$. Another study indicates that an increase in $\mathrm{pH}$ from 4 to 5 reduces all of these parameter ${ }^{28}$. The reaction temperature has also a remarkable influence on the catalyst support properties ${ }^{23}$. In addition, using various surfactants is an effective factor on the proper- ties of alumina catalyst support $\mathrm{t}^{27,29-31}$. Some researchers have exposed that time and temperature of the aging step is one of the most important parameters in this process $^{32-35}$. These results indicate that the specific surface area and the pore size are decreased and increased with escalation of aging time, respectively ${ }^{36}$. The calcination step condition is one of the most important issues in the catalyst support production process. Recent studies showed the type of the alumina that is formed in the process mainly depends on the calcination temperature $^{37-40}$. The investigations revealed that calcination temperature had a major influence on the properties of the alumina catalyst support ${ }^{23,29,30,41}$. Increasing the calcination temperature reduces the specific surface area, the pore volume and the pore size ${ }^{33,42-44}$. The results showed that the biggest surface area was produced in temperature range of $400-450^{\circ} \mathrm{C}^{45}$. The time of calcination is another significant parameter in the process. There is a reduction in the specific surface area when the calcination time is raised ${ }^{32,35,46}$. The speed of the temperature change is also an effective parameter on the characteristics of the alumina ${ }^{46}$.

This study has been conducted to produce alumina catalyst support, using Sol-gel and peptization methods. In the Sol-gel method, aluminum nitrate, aluminum sulphate and aluminum chlorid were used as the aluminum sources. Ammonia, caustic soda, sodium carbonate and sodium aluminate liquor have been used as the alkaline precipitating agents. The roles of the various aluminum sources and precipitators on the specific surface area and compressive strength were investigated, too. In the peptization method, aluminum hydroxide was applied and the effects of $\mathrm{HNO}_{3}$ on the specific surface area and compressive strength of alumina catalyst support were investigated.

\section{Material and compounds analysis}

An electric furnace (Carbolite-RW1400, England), a dryer (Ecocell, England) and a heater equipped with 
temperature control and magnetic stirrer were used to perform the experiments. The quantitative analyses of the compounds in the aluminum hydroxide and alumina were performed using XRF (Siemens-SRS3000, German) and AAS (Unicam, England) devices. The required equipment for measuring the compressive strength has been made. The BET surface area was measured using Strohlein-Aramat II.

The required aluminum nitrate, aluminum sulphate, aluminum chlorid, ammonia, caustic soda, sodium carbonate, $\mathrm{HNO}_{3}$ have been provided from Merck Company products. Aluminum hydroxide (Table 1) produced by Jajarm Alumina Company in Iran was applied for the tests. In addition, the required sodium aluminate solution was prepared and produced using caustic soda from Merck Company. of 4-7 mm, was made using liquid paraffin. Granulated product was washed and dried at a temperature of $110^{\circ} \mathrm{C}$ for 2 hours. In the calcinations step, the dried balls were calcined at the temperature of $550^{\circ} \mathrm{C}$ for 4 hours. In this step, the temperature change rate was set to $5^{\circ} \mathrm{C} / \mathrm{min}$ (Table 3 and Fig. 1).

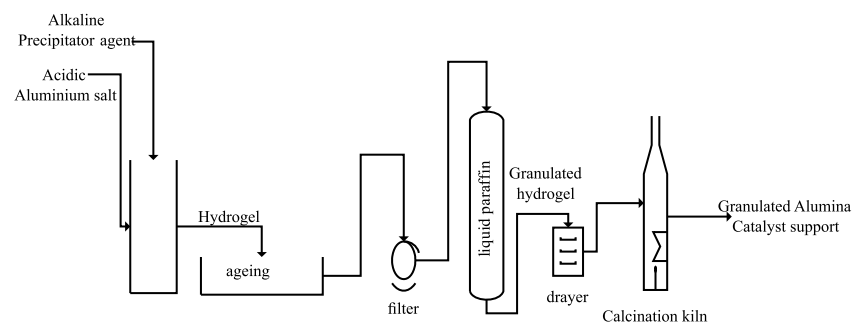

Figure 1. Diagram of the process of alumina catalyst support production, using the Sol-gel method

Table 1. Chemical and physical analysis of the aluminum hydroxide

\begin{tabular}{|l|c|c|c|c|c|c|}
\hline \multirow{2}{*}{ Chemical } & $\mathrm{SiO}_{2}[\%]$ & $\mathrm{Fe}_{2} \mathrm{O}_{3}[\%]$ & $\mathrm{Na}_{2} \mathrm{O}[\%]$ & $\mathrm{CaO}[\%]$ & L.O.I [\%] & Moist [\%] \\
\cline { 2 - 7 } & 0.007 & 0.006 & 0.31 & 0.008 & 34.77 & 9.19 \\
\hline \multirow{3}{*}{ Physical } & \multicolumn{2}{|c|}{ Attrition index } & $<20 \mu \mathrm{m}$ & $<44 \mu \mathrm{m}$ & $<150 \mu \mathrm{m}$ & Median \\
\cline { 2 - 7 } & \multicolumn{2}{|c|}{$\%$} & $\%$ & $\%$ & $\%$ & $\mu \mathrm{m}$ \\
\cline { 2 - 7 } & \multicolumn{2}{|c|}{3.0} & 1.1 & 10.3 & 17.8 & 101.4 \\
\hline
\end{tabular}

\section{DESCRIPTION OF THE EXPERIMENTS}

\section{Sol-gel method}

Sol-gel method was used with the aim of investigating the roles of the various aluminum sources and precipitating agents on the specific surface area and compressive strength (Table 2). Each aluminum salt was separately mixed with different precipitating agents and stirred for $0.5 \mathrm{hr}$. In the experiments $\mathrm{pH}$ was kept constant at

Table 2. Aluminum sources and precipitating agents

\begin{tabular}{|c|c|c|}
\hline $\begin{array}{l}\text { Experiment } \\
\text { No. }\end{array}$ & Aluminum Salt & Precipitating agent \\
\hline 1 & \multirow{4}{*}{ Aluminum Nitrate } & Ammonia \\
\hline 2 & & Caustic soda \\
\hline 3 & & $\begin{array}{l}\text { Sodium } \\
\text { carbonate }\end{array}$ \\
\hline 4 & & $\begin{array}{l}\text { Sodium } \\
\text { Aluminate }\end{array}$ \\
\hline 5 & \multirow{4}{*}{$\begin{array}{l}\text { Aluminum } \\
\text { Sulphate }\end{array}$} & Ammonia \\
\hline 6 & & Caustic soda \\
\hline 7 & & $\begin{array}{l}\text { Sodium } \\
\text { Earbonate }\end{array}$ \\
\hline 8 & & $\begin{array}{l}\text { Sodium } \\
\text { Aluminate }\end{array}$ \\
\hline 9 & \multirow{4}{*}{ Aluminum Chloride } & Ammonia \\
\hline 10 & & Caustic soda \\
\hline 11 & & $\begin{array}{l}\text { Sodium } \\
\text { Carbonate }\end{array}$ \\
\hline 12 & & $\begin{array}{l}\text { Sodium } \\
\text { Aluminate }\end{array}$ \\
\hline
\end{tabular}

9 and then the produced gel was aged for 20 hours at $25^{\circ} \mathrm{C}$. In the next step the produced white hydro gels were filtered, washed and then in the next step, the granulated aluminum hydroxide, having the diameter
Specific surface area and compressive strength of produced alumina catalysts were measured using Strohlein-Aramat II and BET nitrogen adsorption. For measuring compressive strength, the grain of catalyst was placed on a surface and a mobile piston, operated by a stepping motor, crushes the grain. And an electronic device measures the peak value when the grain breaks.

\section{Peptization method}

This study also used peptization of aluminum hydroxide in the producing alumina catalyst support. In the first step, $100 \mathrm{~g}$ of hydrated alumina was heated at $700^{\circ} \mathrm{C}$ for about 0.5 minute and then mixed with water to produce slurry with solid content of $500 \mathrm{~g} / \mathrm{l}$. Then produced slurry was treated using nitric acid. The weight ratio of nitric acid to the alumina hydrate in the experiment was $2.5: 1000$. This mixture was stirred at $70^{\circ} \mathrm{C}$ for 6 hours. Then the hydrated product was dried at $110^{\circ} \mathrm{C}$. In the next step, the produced hydrated alumina was mixed with distilled water to prepare the slurry with the concentration of $250 \mathrm{~g} / \mathrm{l}$ (alumina hydrate). This suspension was mixed with nitric acid. Molar ratio between nitric acid and aluminum hydroxide was 0.05 . The produced slurry has been stirred at $90^{\circ} \mathrm{C}$ for 4 hours. Then treated suspension was filtered and washed to form the granulated alumina hydroxide. Drying and calcination conditions were the same as those for the Sol-gel method conditions.

Table 3. Operation conditions of the producing alumina catalyst support steps, using the Sol-gel method

\begin{tabular}{|c|c|c|c|c|c|c|c|c|c|}
\hline \multicolumn{3}{|c|}{ Reaction step } & \multicolumn{2}{c|}{ aging step } & \multicolumn{2}{c|}{ drying step } & \multicolumn{3}{c|}{ Calcinations step } \\
\hline Temp $\left[{ }^{\circ} \mathrm{C}\right]$ & $\mathrm{pH}$ & Time $[\mathrm{h}]$ & Temp $\left[{ }^{\circ} \mathrm{C}\right]$ & Time $[\mathrm{h}]$ & Temp $\left[{ }^{\circ} \mathrm{C}\right]$ & Time $[\mathrm{h}]$ & Temp $\left[{ }^{\circ} \mathrm{C}\right]$ & Temp rate $\left[{ }^{\circ} \mathrm{C} / \mathrm{min}\right]$ & Time $[\mathrm{h}]$ \\
\hline 25 & 9 & 0.5 & 25 & 20 & 110 & 2 & 550 & 5 & 4 \\
\hline
\end{tabular}




\section{RESULTS AND DISCUSSION}

\section{Sol-gel method}

As mentioned above, the production conditions have direct influences on characteristics of the alumina. Therefore, in the experiments, these conditions were kept constant as presented in Table 3 and various acidic aluminum salts and alkaline precipitators have been used to produce alumina catalyst support. Specific surface area, compressive strength and the Catalyst support diameter are given in Table 4.

Table 4. Characteristics of the Sol-gel method products

\begin{tabular}{|l|c|c|c|}
\hline $\begin{array}{l}\text { Exp. } \\
\text { No }\end{array}$ & $\begin{array}{c}\text { Specific } \\
\text { surface } \\
\text { area } \\
{\left[\mathrm{m}^{2} / \mathrm{g}\right]}\end{array}$ & $\begin{array}{c}\text { Compressive } \\
\text { strength }\left[\mathrm{kg} / \mathrm{cm}^{3}\right]\end{array}$ & $\begin{array}{c}\text { Catalyst support } \\
\text { diameter }[\mathrm{mm}]\end{array}$ \\
\hline 1 & 300 & 0.5 & 4.0 \\
\hline 2 & 209 & 1.1 & 7.6 \\
\hline 3 & 96 & 0.4 & 6.5 \\
\hline 4 & 164 & 9.0 & 6.5 \\
\hline 5 & 51 & 0.2 & 4.0 \\
\hline 6 & 245 & 14.9 & 4.6 \\
\hline 7 & 61 & 2.0 & 5.0 \\
\hline 8 & 176 & 2.0 & 8.0 \\
\hline 9 & 208 & 0.3 & 4.8 \\
\hline 10 & 154 & 20.1 & 3.5 \\
\hline 11 & 73 & 2.1 & 6.0 \\
\hline 12 & 236 & 2.0 & 8.3 \\
\hline
\end{tabular}

Effect of various alkaline precipitators on alumina catalyst support characteristics

Investigating the precipitator type on the specific surface area and compressive strength of the alumina catalyst support has been performed in this study. These results are given in the Figures 2-7.

Effect of various precipitators on specific surface area in the presence of aluminum nitrate

Aluminum nitrate salt and various precipitators have been used to produce alumina catalyst support. Specific surface area of these products were measured and presented in Figure 2. Figure 2 shows that ammonia produces the highest specific surface area $\left(300 \mathrm{~m}^{2} / \mathrm{g}\right)$ whereas sodium carbonate causes the lowest specific surface area $\left(96 \mathrm{~m}^{2} / \mathrm{g}\right)$. The results also indicate using sodium hydroxide and sodium aluminate solutions lead the specific surface area of 209 and $164 \mathrm{~m}^{2} / \mathrm{g}$, respectively.

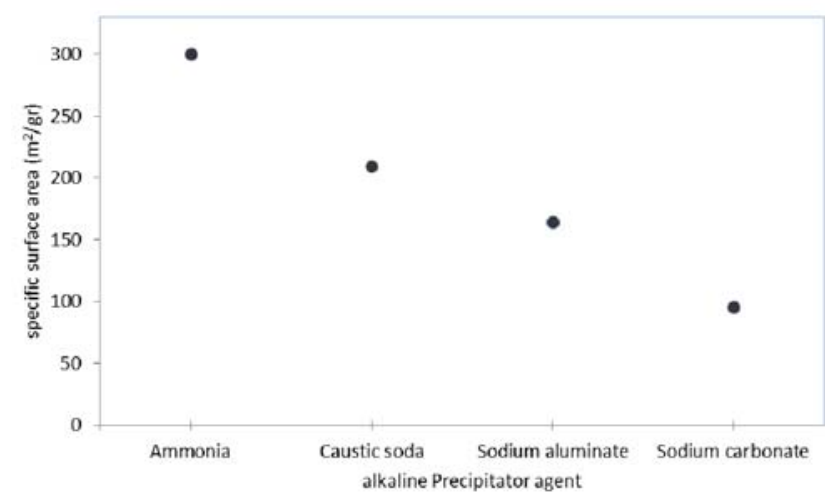

Figure 2. The effects of various alkaline precipitators on the specific surface area in alumina catalyst support produced by aluminum nitrate
Effect of various precipitators on specific surface area in the presence of aluminum sulfate

Figure 3 shows the specific surface area of alumina catalyst supports, which were made from aluminum sulfate. In this case, the carrier produced from sodium hydroxide solution with specific surface area of $245 \mathrm{~m}^{2} / \mathrm{g}$, has the highest value whereas the carrier produced from ammonia causes the catalyst supports has the lowest specific surface area of $51 \mathrm{~m}^{2} / \mathrm{g}$.

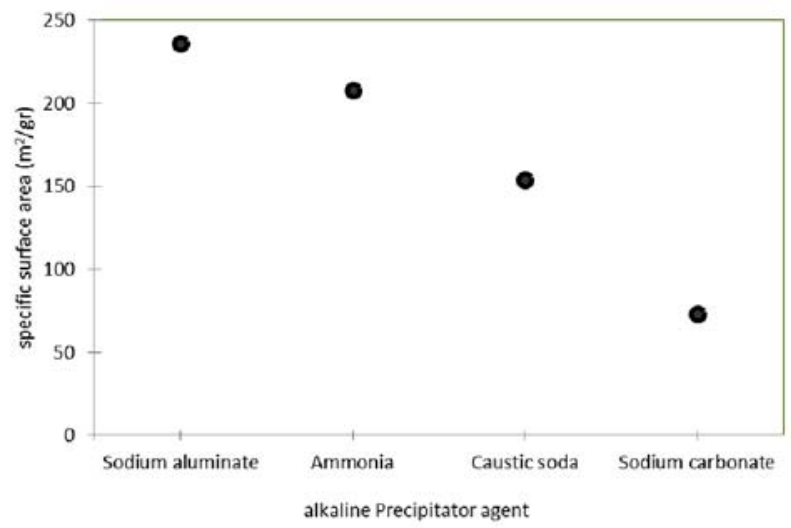

Figure 3. The effect of various alkaline precipitators on the specific surface area of the alumina catalyst support produced from aluminum sulfate

Effect of various precipitators on the specific surface area in the presence of aluminum chloride

Figure 4 shows the alumina catalyst support produced using aluminum chloride salt and $236 \mathrm{~m}^{2} / \mathrm{g}$ sodium aluminate as the precipitating agent leads to the largest value of specific surface area compared to other precipitators. These results also indicate that sodium carbonate leads the catalyst carrier with the lowest BET.

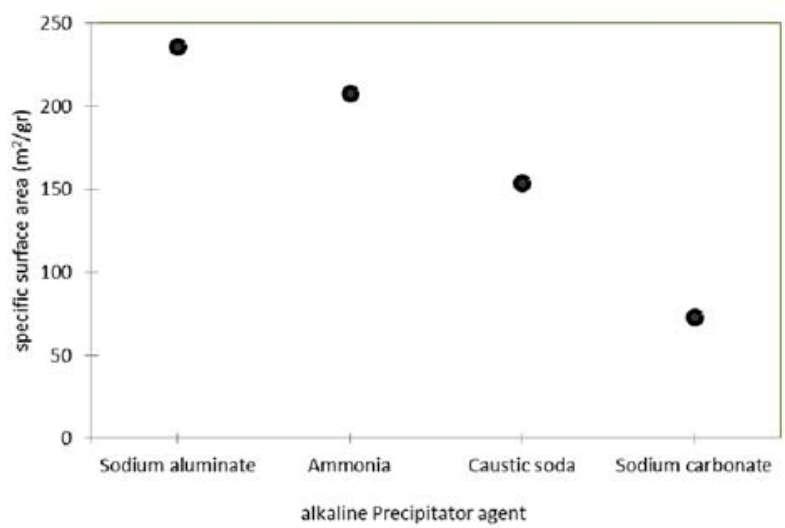

Figure 4. The effect of various alkaline precipitators on specific surface area of alumina catalyst support produced by aluminum chloride

Effect of various precipitators on compressive strength in the presence of aluminum nitrate

Figure 5 shows the results of the investigation of the various alkaline precipitators and acidic aluminum sources effects on compressive strength of alumina catalyst support in the presence of aluminum nitrate. The results indicate the alumina produced using sodium aluminate has the greatest compressive strength compared to others. The Figure also shows sodium carbonate has the lowest compressive strength among the precipitators. 


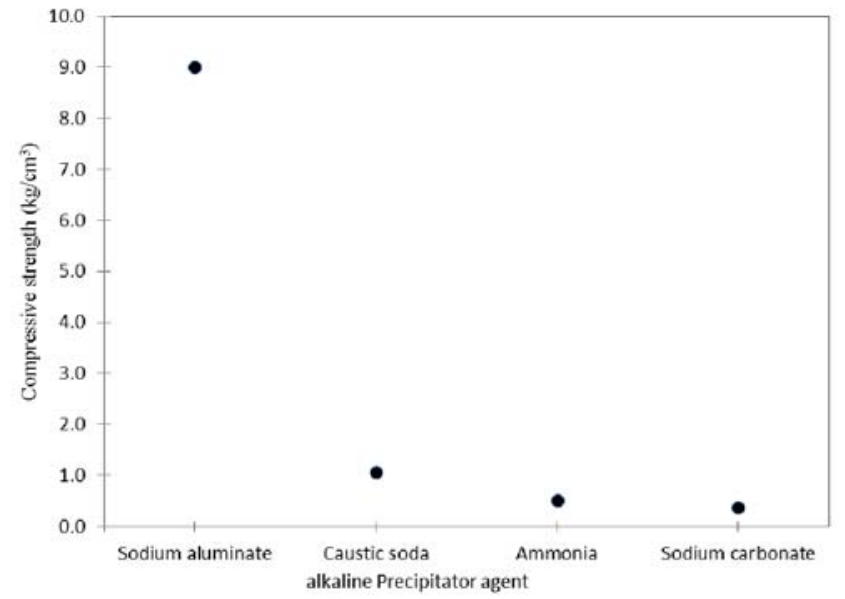

Figure 5. The effect of various alkaline precipitators on compressive strength of alumina catalyst support produced by aluminum nitrate

Effect of various precipitators on compressive strength in the presence of aluminum sulfate

Figure 6 shows the compressive strength of the alumina catalyst supports that were produced from aluminum sulfate salt and the various precipitators. The results indicate that sodium hydroxide can produce alumina catalyst carrier with the highest compressive strength compared to the other precipitators. The Figure also shows that the catalyst carrier prepared using ammonia has the lowest compressive strength among various precipitators.

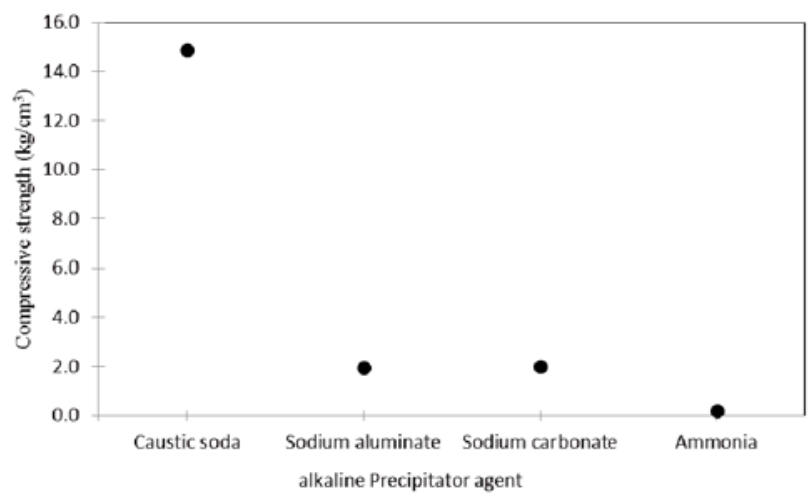

Figure 6. The effect of various alkaline precipitators on compressive strength of alumina catalyst support produced by aluminum sulfate

Effect of various precipitators on compressive strength in the presence of aluminum chloride

Figure 7 shows using aluminum chloride salt and sodium hydroxide as the precipitator has produced alumina catalyst support with compressive strength of 20.1 $\mathrm{kg} / \mathrm{cm}^{3}$. That means its compressive strength is much higher than other carriers. This Figure also exposes that alumina catalyst support produced applying ammonia has the lowest amount of compressive strength $\left(0.3 \mathrm{~kg} / \mathrm{cm}^{3}\right)$.

\section{Peptization method}

In this study, peptization method has also been used to prepare alumina catalyst support. In the treating process, nitric acid is also been applied. Table 5 shows the alumina catalyst carrier specific surface area, compressive strength and the catalyst support diameter. The results show that peptization method causes the alumina to have specific
Table 5. Characteristics of the alumina catalyst support produced by peptization method

\begin{tabular}{|l|c|c|c|}
\hline $\begin{array}{l}\text { Experiment } \\
\text { No }\end{array}$ & $\begin{array}{c}\text { specific } \\
\text { surface } \\
\text { area }\left[\mathrm{m}^{2} / \mathrm{g}\right]\end{array}$ & $\begin{array}{c}\text { Compressive } \\
\text { strength }\left[\mathrm{kg} / \mathrm{cm}^{3}\right]\end{array}$ & $\begin{array}{c}\text { Catalyst } \\
\text { support } \\
\text { diameter }[\mathrm{mm}]\end{array}$ \\
\hline 13 & 200 & 0.3 & 0.4 \\
\hline
\end{tabular}

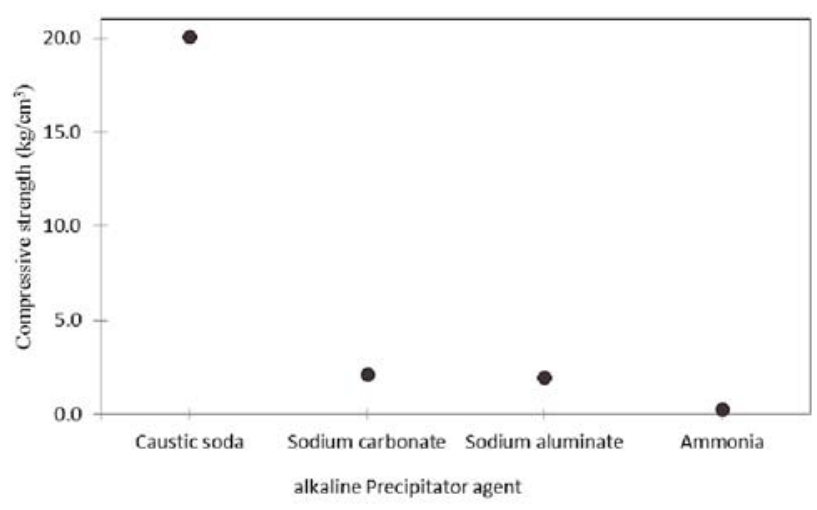

Figure 7. The effect of various alkaline precipitators on compressive strength of alumina catalyst support produced by aluminum chloride

surface area of $200 \mathrm{~m}^{2} / \mathrm{g}$. It is very important to mention that in this study no additive has been used to increase BET and compressive strength. In this condition as shown in Table 5, the compressive strength is $0.3 \mathrm{~kg} / \mathrm{cm}^{3}$.

Comparison of the effects of various aluminum salts and precipitators on specific surface area and compressive strength

Comparison of the effect of various aluminum salts on the specific surface area and compressive strength using average amount of these data in the presence of different precipitators are shown in Figure 8. The results show that the alumina catalyst carriers has been produced using aluminum nitrate and aluminum sulfate with specific surface area of $192.25 \mathrm{~m}^{2} / \mathrm{g}$ and $133.25 \mathrm{~m}^{2} / \mathrm{g}$, respectively. The study of the impacts of using various aluminum salts on compressive strength indicates that the catalyst support prepared from aluminum chloride and aluminum nitrate leads to the maximum and minimum amounts of compressive strength.

The average amount of specific surface area and compressive strength of aluminum catalysts supports produced from various alkaline precipitators are presented in Figure 9. The results show that alumina catalyst supports produced using sodium hydroxide and sodium carbonate

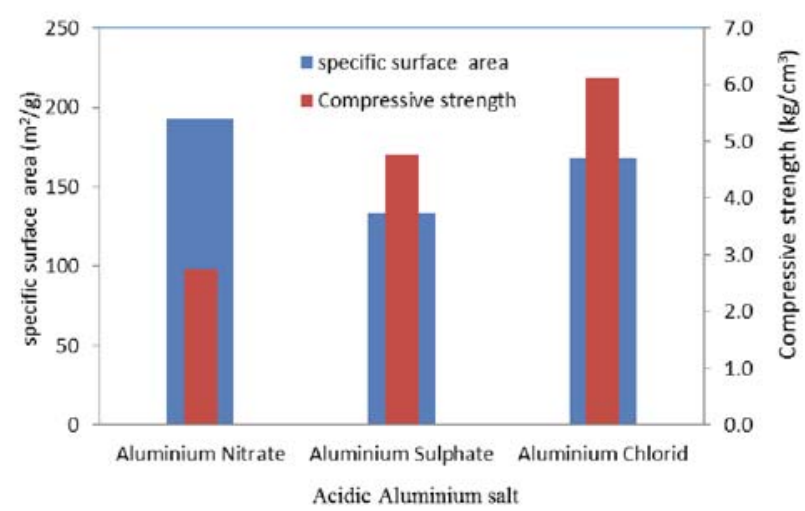

Figure 8. The effect of various aluminum salts on compressive strength and specific surface area of alumina catalyst support 
with specific surface area of $202.7 \mathrm{~m}^{2} / \mathrm{g}$ and $76.7 \mathrm{~m}^{2} / \mathrm{g}$ have the highest and the lowest values, respectively. Also, sodium aluminate has been used to prepare the catalyst support with a high surface area. This study indicates that various precipitators have different influences on the compressive strength. Figure 9 reveals caustic soda and sodium carbonate applied to make alumina catalyst supports with the highest and the lowest compressive strength. These results also show that sodium aluminate causes the product to have high compressive strength.

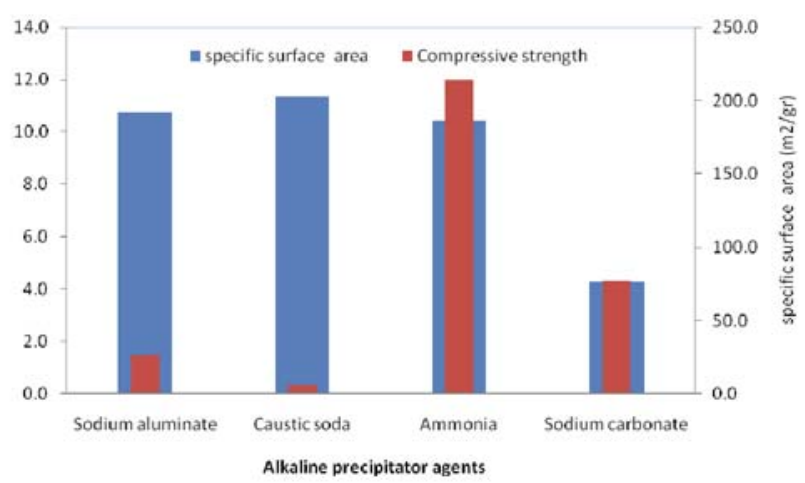

Figure 9. The effect of various alkaline precipitators on compressive strength and specific surface area of alumina catalyst support

All comparison results of the effects of various aluminum salts and precipitator agents on the specific surface area and compressive strength is summarized and presented in Table 6.

Table 6. Effects of various aluminum salts and precipitator agents on the specific surface area and compressive strength

\begin{tabular}{|l|c|c|}
\hline \multirow{2}{*}{ Aluminum salts } & $\begin{array}{c}\text { Specificsurface } \\
\text { area }\end{array}$ & $\begin{array}{c}\text { Compressive } \\
\text { strength }\end{array}$ \\
\cline { 2 - 3 }$\left[\mathrm{m}^{2} / \mathrm{gr}\right]$ & {$\left[\mathrm{kg} / \mathrm{cm}^{3}\right]$} \\
\hline Aluminium Nitrate & 192.25 & 2.7 \\
\hline Aluminium Sulphate & 133.25 & 4.8 \\
\hline Aluminium Chlorid & 167.75 & 6.1 \\
\hline \multirow{3}{*}{ Alkaline precipitators } & $\begin{array}{c}\text { Specific surface } \\
\text { area }\end{array}$ & $\begin{array}{c}\text { Compressive } \\
\text { strength }\end{array}$ \\
\cline { 2 - 3 }$\left[\begin{array}{c}{\left[\mathrm{m}^{2} / \mathrm{gr}\right]} \\
{\left[\mathrm{kg} / \mathrm{cm}^{3}\right]}\end{array}\right.$ \\
\hline Sodium carbonate & 76.7 & 1.5 \\
\hline Ammonia & 186.3 & 0.3 \\
\hline Caustic soda & 202.7 & 12.0 \\
\hline Sodium aluminate & 192 & 4.3 \\
\hline
\end{tabular}

\section{CONCLUSION}

This research has achieved appropriate pairs of salt and precipitator for producing alumina catalyst supports with the large of specific surface area and compressive strength. The results show that based on Sol-gel method, aluminum nitrate salt along with the ammonia as a precipitating agent produced alumina catalyst support with $300 \mathrm{~m}^{2} / \mathrm{g}$ of specific surface area. The catalyst carrier with the highest compressive strength of $20 \mathrm{~kg} / \mathrm{cm}^{3}$ has been prepared from aluminum chloride and sodium hydroxide. The results also indicate that alumina catalyst supports prepared from aluminum nitrate and aluminum chloride have the largest specific surface area and compressive strength, respectively. Among various precipitators in the presence of different aluminum sources exposes, sodium hydroxide and sodium aluminate have produced the supports with the highest values BET of 202.7 and $192 \mathrm{~m}^{2} / \mathrm{g}$, respectively. These results also indicate that sodium hydroxide causes the carrier to have the largest compressive strength compared to the other precipitating agents. Furthermore, in the study, peptization method has been used to produce alumina catalyst support with specific surface area of $200 \mathrm{~m}^{2} / \mathrm{g}$ and compressive strength of $0.3 \mathrm{~kg} / \mathrm{cm}^{3}$.

\section{ACKNOWLEDGEMENTS}

This work was funded by Iran Alumina Company. The authors thank the anonymous referees for suggesting various improvements to this work, and would like to acknowledge the support of the Iran Alumina Company manager. The authors would also wish to acknowledge Parviz Kelidari, Reza Salimi, Neda Rezvani and Hossein Khabbazzadeh for their valuable discussions.

\section{LITERATURE CITED}

1. Trueba, M. \& Trasatti, S.P. (2005). $\gamma$-Alumina as a Support for Catalysts: A Review of Fundamental Aspects, Eur. J. Inorg. Chem. 2005, 3393-3403. DOI: 10.1002/ejic.200500348.

2. Faure, R., Rossignol, F., Chartier, T., Bonhomme, C., Getchegoyen, A., Del Gallo, P. \& Gary, D. (2010). Alumina foam catalyst supports for industrial steam reforming processes, J. Eurp. Cer. Soc. 31, 303-312. DOI: 10.1016/j.jeurceramsoc.2010.10.009.

3. Mcfarlane, A.R., Silverwood, I.P., Norris, E.L., Ormerod, R.M., Frost, C.D., Parker, S.F. \& Lennon, D. (2013). The application of inelastic neutron scattering to investigate the steam reforming of methane over an alumina-supported nickel catalyst, J. Chem. Physics 427, 16577-16589. DOI: 10.1016/j. chemphys.2013.10.012.

4. Nakano, K., Ali, S.A., Kim, H.J., Kim, T., Alhooshani, K., Park, J.I. \& Mochida, I. (2013). Deep desulfurization of gas oil over NiMoS catalysts supported on alumina coated USY-zeolite, J. Fuel Proc. Technol. 116, 44-51. DOI: 10.1016/j. fuproc.2013.04.012.

5. Antoniak, K., Kowalik, P., Próchniak, W., Konkol, M., Wach, A., Kuśtrowski, P. \& Ryczkowski, J. (2013). Effect of flash calcined alumina support and potassium doping on the activity of Co-Mo catalysts in sour gas shift process, J. Appl. Catal. 423, 114-120. DOI: 10.1016/j.apcata.2012.02.028.

6. Rui, Z., Chen, C., Lu, Y. \& Ji, H. (2014). Anodic Alumina Supported Pt Catalyst for Total Oxidation of Trace Toluene, Chinese. J. Chem. Eng. 22, 882-887. DOI: 10.1016/j. cjche.2014.06.011.

7. Valdez, R., Pawelec, B., Quintana, J.M. \& Olivas, A. (2012). Effect of the acidity of alumina over Pt, Pd, and Pt-Pd (1:1) based catalysts for 2-propanol dehydration reactions. J. Fuel 105, 688-694. DOI: 10.1016/j.fuel.2012.10.047.

8. Persson, K., Thevenin, P.O., Jansson, K., Agrell, J., Järås, S.G. \& Pettersson, L.J. (2003). Preparation of alumina-supported palladium catalysts for complete oxidation of methane J. Appl. Catal. 249, 165-174. DOI: 10.1016/S0926$-860 \mathrm{X}(03) 00193-5$.

9. Banga, Y., Hana, S.J., Seob, J.G., Youna, M.H., Songa, J.H. \& Songa, I.K. (2012). Hydrogen production by steam reforming of liquefied natural gas (LNG) over ordered mesoporous nickel-alumina catalyst, Int. J. Hydrogen Energy.38, 17967-17977. DOI: 10.1016/j.ijhydene.2013.05.029.

10. Ganley, J.C., Riechmann, K.L., Seebauer, E.G. \& Masel, R.I. (2004). Porous anodic alumina optimized as a catalyst support for microreactors, J. Catal. 227, 26-32. DOI: 10.1016/j. jcat.2004.06.016.

11. Yun, S.J. \& Seo, Y. (2013). Removal of bacteria and odor gas by an alumina support catalyst and negative air ions. J. Aerosol Sci. 58, 33-40. DOI: 10.1016/j.jaerosci.2012.12.006. 
12. Rodrigues, R., Isoda, N., Gonçalves, M., Figueiredo, F.C.A., Mandelli, D. \& Carvalho, W.A. (2012). Effect of niobia and alumina as support for Pt catalysts in the hydrogenolysis of glycerol. Chem. Eng. J. 198-199, 457-467. DOI: 10.1016/j. cej.2012.06.002.

13. Garg, A.K. (1996). Firing sol-gel alumina particles, International publication number, Appl. WO1996032226A2.

14. Wakabayashi, M., Ono, T., Togari, O. \& Nakamura, M. (1981). Process for the production of alumina suiTable for use as a catalyst carrier, United States Patent, Appl. US4248852 A.

15. Crişan, M., Zaharescu, M., Durga, Kumari, V., Subrahmanyam, M., Crişan, D., Drăgan, N., Răileanu, M., Jitianu, M., Usu, R.A., Sadanandam, G. \& Krishna Reddy, J. (2011). Sol-gel based alumina powders with catalytic applications, J. Appl. Surf. Sci. 258, 448-455. DOI: 10.1016/j.apsusc.2011.08.104.

16. Ginestra, J.M., Ackerman, R.C. \& Michel, C.G. (2006). Alumina having bimodal pore structure, catalysts made thereform and process using same, United States Patent, Appl. US6984310 B2.

17. Becker, L.W. \& Lukas, J.B. (1989). Manufacture and use of polymer modified aluminum hydroxide and basic aluminum sulfate, United States Patent, Appl. US4826606 A.

18. Bloc, J. \& Ville, R. (1987). Dispersible alpha alumina monohydrate having increased viscosifying properties, United States Patent, Appl. US4584108 A.

19. Papayannakos, N.G., Thanos, A.M. \& Kaloidas, Y.E. (1993). Effect of seeding during precursor preparation on the pore structure of alumina catalyst supports, J. Microporous Mater. 1, 423-430. DOI: 10.1016/0927-6513(93)80036-T.

20. Da Ros, S., Barbosa-Coutinho, E., Schwaab, M., Calsavara, V. \& Fernandes-Machado, N.R.C. (2013). Modeling the effects of calcination conditions on the physical and chemical properties of transition alumina catalysts, J. Mater. Charact. 80, 50-61. DOI: 10.1016/j.matchar.2013.03.005.

21. Oberlander, K. (1984). Applied Industrial Catalysis, Academic Press, New York, 63.

22. Wefers, K. (1990). Alumina Chemicals: Science and Technology Handbook, Edited by L.D. Hart and E. Lense, The American Ceramic Society, Westerville, Ohio, 13.

23. Ray, J.C., You, K.S., Ahn, J.W. \& Ahn, W.S. (2007). Mesoporous alumina (I): Comparison of synthesis schemes using anionic, cationic, and non-ionic surfactants. Micropor. Mesopor. Mater. 100, 183-190. DOI: 10.1016/j.micromeso.2006.10.036.

24. Čejka, J., Žilková, N., Rathouský, J. \& Zukal, A. (2001). Nitrogen adsorption study of organised mesoporous alumina. Phys. Chem. Chem. Phys. 3, 5076-5081. DOI: 10.1039/B105603B.

25. Čejka, J., Veselá, L., Rathouský, J. \& Zukal, A. (2002). Adsorption of nitrogen on organized mesoporous alumina. Stud. Surf. Sci. Catal. 141, 429-436. DOI: 10.1016/S01672991(02)80572-9.

26. Kim, Y., Kim. C., Kim. P. \& Yi, J. (2005). Effect of preparation conditions on the phase transformation of mesoporous alumina. J. Non-Crystalline Sol. 351, 550-556. DOI: 10.1016/j. jnoncrysol.2005.01.009.

27. Valange, S., Guth, J.L., Kolenda, F., Lacombe, S. \& Gabelica, Z. (2000). Synthesis strategies leading to surfactant-assisted aluminas with controlled mesoporosity in aqueous media. Micropor. Mesopor. Mater 35-36, 597-607. DOI: 10.1016/S1387-1811(99)00253-X.

28. Xu, B., Xiao, T., Yan, Z., Sun, X., Sloan, J., González-Cortés, S.L., Alshahrani, F. \& Green, M.L.H. (2006). Synthesis of mesoporous alumina with highly thermal stability using glucose template in aqueous system. Micropor. Mesopor. Mater 91, 293-295. DOI: 10.1016/j.micromeso.2005.12.007.

29. González-Peña, V., Márquez-Alvarez, C., Sastre, E. \& Pérez-Pariente, J. (2001). Improved Thermal Stability of Mesoporous Alumina Support of Catalysts for the Isomerization of Light Paraffins. Stud. Surf. Sci. Catal. 135, 1072-1079. DOI: 10.1016/S0167-2991(01)81400-2.
30. Acosta, S., Ayral, A., Guizard, C. \& Cot, L. (1996). Synthesis of alumina gels in amphiphilic media. J. Sol-Gel. Sci. Technol. 8, 195-199. DOI: 10.1007/BF02436840.

31. Zhang, Z. \& Pinnavaia, Mesostructured, T.J. (2002). $\gamma-\mathrm{Al}_{2} \mathrm{O}_{3}$ with a Lathlike Framework Morphology. J. Am. Chem. Soc. 124, 12294-12301. DOI: 10.1021/ja0208299.

32. Vaudry, F., Khodabandeh, S. \& Davis, M.E. (1996). Synthesis of pure alumina mesoporous materials. Chem. Mater. 8, 1451-1464. DOI: 10.1021/cm9600337.

33. González-Peña, V., Márquez-Alvarez, C., Sastre, E. \& Pérez-Pariente, J. (2002). Synthesis of ordered mesoporous and microporous aluminas: strategies for tailoring texture and aluminum coordination. Stud. Surf. Sci. Catal. 142, 1283-1290. DOI: 10.1016/S0167-2991(02)80291-9.

34. González-Peña, V., Márquez-Alvarez, C., Díaz, I., Grande, M., Blasco, T. \& Pérez-Pariente, J. (2005). Sol-gel synthesis of mesostructured aluminas from chemically modified aluminum sec-butoxide using non-ionic surfactant templating. Micropor. Mesopor. Mater. 80, 173-182. DOI: 10.1016/j.micromeso.2004.12.011.

35. Deng, W., Bodart, P., Pruski, M. \& Shanks, B.H. (2002). Characterization of mesoporous alumina molecular sievessynthesized by nonionic templating. Micropor. Mesopor.Mater. 52, 169-177. DOI: 10.1016/S1387-1811(02)00315-3.

36. Shan, Z., Jansen, J.C., Zhou, W. \& Maschmeyer, T. (2003). Al-TUD-1, sTable mesoporous aluminas with high surface areas. Appl. Catal. A: General 254, 339-343. DOI: 10.1016/S0926-860X(03)00480-0.

37. Li, W.C., Lu, A.H., Schmidt, W. \& Schüth, F. (2005). High surface area, mesoporous, glassy alumina with a controllable pore size by nanocasting from carbon aerogels. Chem.-A Eur. J. 11, 1658-1664. DOI: 10.1002/chem.200400776.

38. Dey, S.(2014). Synthesis and Application of $\gamma$-Alumina Nanopowders, National Institute of Technology, Rourkela, India, 1-17.

39. Liu, C., Liu, Y., Ma, Q. \& He, H. (2010). Mesoporous transition alumina with uniform pore structure synthesized by alumisol spray pyrolysis, Chem. Eng. J. 163, 133-142. DOI: 10.1016/j.cej.2010.07.046.

40. Siriwardane, U., Seetala, N.V., Vegesna, N.S., Vudarapu, S. \& Luurtsema, K. (2006). Comparison of $\mathrm{Fe} / \mathrm{Co} / \mathrm{Cu}$ metal loading in mesoporous $\gamma$-alumina prepared by three sol-gel methods, Submitted to Appl. Catal.: A General, 17.

41. Zhu, H.Y., Riches, J.D. \& Barry, J.C. (2002). gamma-alumina nanofibers prepared from aluminum hydrate with poly(ethylene oxide) surfactant. Chem. Mater, 14, 2086-2093. DOI: $10.1021 / \mathrm{cm} 010736 \mathrm{a}$.

42. González-Peña, V., Díaz, I., Márquez-Alvarez, C., Sastre, E. \& Pérez-Pariente, J. (2001). Thermally sTable mesoporous alumina synthesized with non-ionic surfactants in the presence of amines. Micropor. Mesopor. Mater. 44, 203-210. DOI: 10.1016/S1387-1811(01)00185-8.

43. Boissière, C., Nicole, L., Gervais, C., Babonneau, F., Antonietti, M., Amenitsch, H., Sanchez, C. \& Grosso, D. (2006). Nanocrystalline mesoporous gamma-alumina powders "UPMC1 material" gathers thermal and chemical stability with high surface area, Chem. Mater. 18, 5238-5243. DOI: $10.1021 / \mathrm{cm} 061489 \mathrm{j}$.

44. Liu, X., Wei, Y., Jin, D. \& Shih, W.H. (2000). Synthesis of mesoporous aluminum oxide with aluminum alkoxide and tartaric acid. Mater. Lett. 42, 143-149. DOI: 10.1016/S0167-577X(99)00173-1.

45. Ren, T.Z., Yuan, Z.Y. \& Su, B.L. (2004). Microwave-assisted preparation of hierarchical mesoporous-macroporousboehmite $\mathrm{AlOOH}$ and gamma- $\mathrm{Al}_{2} \mathrm{O}_{3}$. Langmuir 20, 1531-1534. DOI: $10.1021 / \mathrm{la} 0361767$.

46. Yada, M., Hiyoshi, H., Ohe, K., Machida, M. \& Kijima, T. (1997). Synthesis of aluminum-based surfactant mesophases morphologically controlled through a layer to hexagonal transition. Inorg. Chem. 36, 5565-5569. DOI: 10.1021/ic970292d. 